\title{
SISTEM EKONOMI KAPITALISME DAN SOSIALISME
}

\author{
Muthmainnah Sultan (90100118119) \\ Fakultas Ekonomi dan Bisnis Islam UIN Alauddin Makassar \\ E-mail : muthmainnahsultan7@gmail.com
}

\begin{abstract}
Kesenjangan atau ketimbangan ekonomi adalah suatu keadaan yang ketidakseimbangan di masyarakat yang mengankibatkan adanya perbedaan kekayaan (Hadrianov \& Antoni, 2019). Berdasarkan data statistik jumlah penduduk bumi terdapat 5 milyar di dunia dan kita hanya dapat nmenganbil sebanyak 359 orang yang terbilang kaya dibandingkan dengan orang miskin yang hanya 2,9 milyar disini dapat kita ketahui bahwa jumlah orang terkaya di dunia setara dengan jumlah kekayaaan separuh jumlah penduduk bumi. Dan jika 3 orang terkaya di dunia bila kita gabungkan itu sama dengan Gross domestic product (GDP) 48 Negara termiskin. Dengan demikian jika orang kaya lebih banyak dibandingkan dengan orang miskin maka ini akan menimbulkan suatu permasalahan dalam hal ketersedian kebutuhan dasar yaitu makanan, air, pendidikan dan kesehatan. Lebih lanju untuk mengatasi permasalahan kelaparan, kekurangan gizi, dan wabah penyakit dibutuhkan penghimpun dana kekayaan sebesar 4\% dari 225 orang terkaya di dunia. Maka dari data tersebut menunjukkan bahwa terdapat sebuah kontadiksi yang sangat mendasar dalam masyarakat kita saat ini. Sangat mencengangkan, dimana ditengah-tengah kesejahteraan, kekamakmuran dan kemakmuran terdapat reproduksi kemiskinan, kesengsaraan yang terus menerus terjadi.
\end{abstract}

Sistem ekonomi kapitalis adalah sistem perekonomian yang memberikan kebebasan secara penuh kepada setiap individu untuk melakukan kegiatan perekonomian seperti memproduksi barang, menjual barang, menyalurkan barang dan lain sebagainya. Kapitalisme biasanya melibatkan hak-hak individu dan sekelompok individu yang berperan sebagai orang-orang legal atau korporasikorporasi yang memperdagangkan barang-barang kapital, buruh, dan uang (Yan, 2016). George stiger 
dalam buku Mark Skousen "Sejarah Pemikiran Ekonomi Sang Maestro" menyatakan terkait dengan kapitalisme merupakan gaya ekonomi yang memiliki kebebasan, persaingan bebas dan kepemilikan pribadi (Sirajuddin \& Tamsir, 2019). Dalam sistem ekonomi kapitalisme ini dikenal adanya the money circuit of capital dalam hal ini digambaran smenggunakan rumus :

$$
\mathrm{M}-\mathrm{C}-\mathrm{M}^{\prime}
$$

Maka maksud dari rumus tersebut ada Sirkulasi pertukaran barang dan perubahan uang menjadi komoditas dan berubah lagi menjadi uang (Kambali \& Gresik, n.d.). Modal berupa uang harus menjadi komoitas (C) yang kemudian ini menghasilkan uang kembali namun dengan jumlah lebih. Siklus ini akan terjadi terus menerus sebagai aktivitas mencari keuntungan secra inheren. Selanjutnya dalam melakukan kegiatan Produksi ini tentu perlu adanya faktor pendorong meliputi:

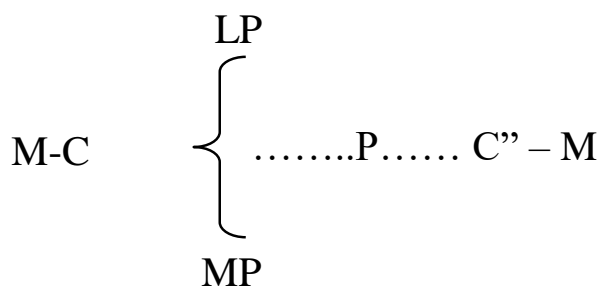

C dibagi menjadi dua bagian, LP atau labor power yang tidak lain adalah para pekerja atau buruh dan MP atau means of production yang merupakan alat produksi yang mendorog proses produksi. Maka dengan terpenuhinya hal tersebut maka akan terjadi ........... atau produksi dan akan menghasilkan komoditas baru dengan nilai lebih (C"). dengan hal inilah para kapitalis mampu memperoleh keuntungan secara terus menerus.

Sistem ekonomi sosialisme merupakan model ekonomi yang diatur oleh negara, dimana perdagangan dan aktivitas perekonomian sepenuhnya menjadi tanggungjawab negara (Effendi, 2019) akan tetapi bukan berarti ekonomi sosialis tidak memberikan 
kebebasan individu dalam aktivitas ekonomi, hak pribadi tetap diberikan kebebasan dalam melakukan aktivitas ekonomi namun tidak begitu leluasa dibandingkan dengan campur tangan pemerintah (Tho'in, 2015) 


\section{DAFTAR PUSTAKA}

Hadrianov, T., \& Antoni, A. (2019). PENGARUH PERTUMBUHAN EKONOMI DAN KETIMPANGAN SOSIAL TERHADAP KEMISKINAN DI SUMATERA BARAT. Jurnal Fakultas Ekonomi, 14(3).

Kambali, M., \& Gresik, S. A.-A. M. (n.d.). Pemikiran Karl Marx Tentang Struktur Masyarakat (Dialektika Infrastruktur Dan Suprastruktur).

Sirajuddin, S., \& Tamsir, T. (2019). REKONSTRUKSI KONSEPTUAL KEPEMILIKAN HARTA PERSPEKTIF EKONOMI ISLAM (Studi Kritis Kepemilikan Harta Sistem Ekonomi Kapitalisme). Laa Maisyir: Jurnal Ekonomi Islam, 6(2), 211-225.

Yan, R. H. (2016). Eksistensi Sistem Ekonomi Kapitalis di Indonesia. Jurnal Ilmiah Al-Syir'ah, 8(1).

Effendi, S. (2019). Perbandingan Sistem Ekonomi Islam Dengan Sistem Ekonomi Kapitalis dan Sosialis. JRAM (Jurnal Riset Akuntansi Multiparadigma), 6(2), 147-158.

Tho'in, M. (2015). Konsep Ekonomi Islam Jalan Tengah (Kapitalis-Sosialis). Jurnal Ilmiah Ekonomi Islam, 1(03). 